\title{
Tarihi Yapılarda Kagir Yapı Malzemelerinin Koruma Uygulamalarında Kullanılabilecek Bir Yöntem Önerisi
}

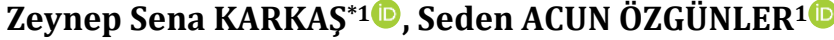 \\ ${ }^{1}$ İstanbul Teknik Üniversitesi, Mimarlık Fakültesi, 34367, İstanbul, Türkiye
}

(Alınış / Received: 21.02.2021, Kabul / Accepted: 12.07.2021, Online Yayınlanma / Published Online: 25.12.2021)

\section{Anahtar Kelimeler \\ Taş sağlamlaştırma \\ Taş koruma \\ Sağlamlaştırıcı \\ Su itici}

Özet: Türkiye'de, birçok farklı medeniyetin izlerini taşıyan tarihi yapıların ve anıtların cephelerinde kullanılan başta doğal taşlar olmak üzere kagir yapı malzemeleri, birçok faktöre bağlı olarak hızla bozulmaktadır. Tarihi yapıların kültürel miras değerinin sürdürülebilirliği için özgün kagir malzemenin yerinde korunması, özellikle eski taş iş̧̧iliğinin de artık yok olmaya başladığı düşünüldüguünde büyük önem arz etmektedir. Bu nedenle, taşların bozulmalarını önleyerek bozulma süreçlerini yavaşlatmak ve bozulma derecelerini azaltmak için taş koruma çalışmaları yapılmaktadır. Bu çalışmalar sırasında yapılan taş sağlamlaștırma uygulamaları kapsamında sağlamlaștırıcı ve/veya su itici kimyasal uygulamalar geliștirilerek kagir yapı malzemelerine uygulanmaktadır. Bu çalıșma sonucunda, Türkiye için yeni sayılan ve konuyla ilgili az çalışma bulunan bir alan olan sağlamlaştırıcı ve su itici kimyasal uygulamalara dikkat çekmek, bilgi birikimi arttırmak, belirli kalitede olmasını sağlamak için Türkiye'de de standartlaşması gerektiğini vurgulayarak bilinçli kullanım konusunda katkı koymak amaçlanmıştır. Tüm bu amaçlar doğrultusunda, dünyada taş sağlamlaștırma çalışmalarında kullanılan uluslararası standartlara ve şartnamelere göre tarihi yapılarda özgün kagir yapı malzemelerini koruma çalışmalarında (özellikle taş koruma çalışmalarında) kullanılabilecek bir yöntem önerisi geliştirilmiştir.

\section{A Method Suggestion That Can Be Used in Conservation of Masonry Materials in Historical Buildings}

\section{Keywords}

Stone consolidation

Stone conservation

Consolidant

Water repellent

\begin{abstract}
In Turkey, masonry building materials, especially natural stones used on the facades of historical buildings and monuments bearing the traces of many different civilizations, are rapidly deteriorating due to many factors. For the sustainability of historical buildings' cultural heritage value, preserving the original masonry material in situ is much more critical, especially since the old stonework is starting to disappear today. For this reason, stone conservation studies are carried out to slow down the deterioration processes and reduce the degree of deterioration by preventing further deterioration of the stones. During these studies, consolidant and/or water repellent chemical applications are developed within the scope of stone consolidation applications and applied to masonry building materials. As a result of this research, it is aimed to draw attention to consolidant and/or waterrepellent chemical applications, which are few studies on the subject in Turkey, to increase knowledge. And then, it is aimed to emphasize the need for standardization in Turkey and contribute to the intended use of these irreversible chemical applications to have a certain quality. In line with these purposes, a method proposal has been developed that can be used to preserve original masonry building materials in historical buildings, especially in stone conservation studies, according to the international standards and specifications used in stone consolidation studies in the world.
\end{abstract}




\section{Giriş}

Ait oldukları dönemin sosyal, siyasal, kültürel ve mimari yapısını yansıtarak tarihsel sürekliliği sağlayan ve her biri adeta yaşayan birer kültürel hafıza olan tarihi yapılar ve anıtlar, başta çeşitli doğal taşlar ve tuğlalar olmak üzere kagir yapı malzemeleri kullanılarak inşa edilmiştir. Özellikle tarihi yapılarda kullanılan doğal taşlar, taşıyıcı özellikleri güçlü olduğu için sağlam yapılar yapmaya olanak sağlaması, güvenilir olması, özgün malzeme olması ve doğada bol miktarda bulunması gibi nedenlerden dolayı yüzyıllar boyunca mimaride yapı malzemesi olarak kullanılmıștır $[1,2,3,4]$.

19. yüzyıldaki endüstriyel gelişme nedeniyle hava kalitesinin gittikçe kötüleşmesi, özellikle tarihi yapıların cephelerinde kullanılan kagir yapı malzemelerinin çok hızlı bir şekilde bozulmasına neden olmuştur. Kagir yapı malzemelerinden olup genellikle tarihi yapılarda yapı taşı olarak kullanılan doğal taşlar, bozulma sırasında deformasyona uğrar ve taşların fiziko-mekanik özellikleri değişerek dayanımı azalır, kırılganlığı ve gözenekliliği artar [1, 5]. Taş korumada en uygun yöntemleri geliştirmek için taş bozulmasından sorumlu faktörlerin anlaşılması gerekir. $\mathrm{Bu}$ nedenle, bozulma mekanizmalarını anlamak, taş dayanıklılığını artıracak ve bakım maliyetlerini düşürecek çözümler bulmak için 19. yüzyılda, zamanla birçok çalışma yapılmıştır [6]. Bu çalışmalarla birlikte, 19. yüzyılın ilk dönemlerinde "sağlamlaştırma" terimi, ilk olarak literatüre girmiş olup sonrasında, 19. yüzyıl ortalarında taş yapıları koruma kaygılarının oluşmasıyla "stone conservation" olarak adlandırılan taş koruma bilimi literatürde yerini almıştır. Taş koruma bilimi ile birlikte yapı taşlarının bozulmasına ve korunmasına yönelik bilimsel araştırmalar başlamıştır. $\mathrm{Bu}$ çalışmalar sonucunda, 20. yüzyılda İkinci Dünya Savaşı sonrası, taşların dayanıklılığını arttırmak için sentetik polimerler geliştirilerek kullanılmaya başlanmıştır [7, 8, 2]. Polimer kimyasının gelişmesi, sentetik polimerlerin performanslarını değerlendirmek için hem uygulama yapılmış hem de uygulama yapılmamış taş örnekleri üzerinde çeşitli fiziksel ve mekanik parametrelerin ölçülebileceği test metodolojilerinin geliştirilmesini teşvik etmiştir. Böylece, taşın korunmasına yönelik uluslararası konferanslar, 1960 ve 1980'ler arasında düzenli olarak düzenlenmiştir. $\mathrm{Bu}$ konferanslar sırasında birçok araştırmacl, sağlamlaştırıcı ve su itici malzemelerin etkinliğini değerlendirmek için oluşturdukları deney programlarına ilişkin çeşitli yayınlar yapmışlardır. Yapılan bu çalışmalarda kullanılan deney yöntemlerinin farklı olması, çalışma sonuçlarının karşılaştırılamamasına yol açmıştır. Bu nedenle birçok test yöntemi komisyonlar kurularak standartlaştırılmıştır $[6,9,2]$.

İlk olarak, RILEM (Réunion Internationale des Laboratoires et Experts des Matériaux, Systèmes de
Construction et Ouvrages), Comission 25-PEM (Protection et Érosion des Monuments) ve 59-TPM (Traitement des monuments en Pierre) Çalışma Grupları (1980), su itici ve sağlamlaştırıcı uygulamalarının etkinliğinin değerlendirilmesi için çeşitli yöntemler önermişlerdir. Sonrasında, İtalyan Komisyonu NORMAL (Normativa Manufatti Lapidei), 2000 yilında UNI (Ente Nazionale Italiano di Unificazione) adı altında, taş malzemelerin bozulmasına ilişkin çalışma yöntemlerini standartlaştırmayı ve koruma işlemlerinin etkinliğini değerlendirmeyi amaçlayan standartlar yayımlanmıştır [10, 2]. Ayrıca, CEN (Comité Européen de Normalisation) Teknik Komite-346 tarafından, taş koruma için Avrupa standartları EN normlarına entegre etmek için çalışmalar yapılmaktadır. Çalışmalar, İtalyan NORMAL, Alman DIN, Fransız RILEM ve diğer ulusal standart gruplarını içermekte olup çeşitli deney metodları ve koruma programları standartlaştırılmıştır. Ayrıca, günümüzde taş malzemelerin korunmasına yönelik ASTM (American Society for Testing and Materials) tarafından birçok çalışma yapılmakta olup çeşitli standartlar yayınlanmaktadır. Ek olarak, özellikle Amerika Birleşik Devletleri ve İtalya gibi gelişmiş ülkeler taş koruma çalışmaları kapsamında çeşitli yönetmelikler, şartnameler de yayınlamaktadır $[10,6,2]$.

Başta doğal taşlarda olmak üzere kagir yapı malzemelerini sağlamlaştırma uygulamalarında kullanılan uluslararası standartlara, yönetmeliklere ve şartnamelere göre; yüzey uygulamaları, yığma yapılarda ve harçlarda koruma sağlamak ve su girişini azaltmak için geleneksel veya çağdaş kimyasal ürünlerin duvar yüzeyine uygulanması $[11,2]$ taş sağlamlaştırma uygulamaları ise, doğal taş tarafından emilerek taşın gözenekleri içinde sertleşen kimyasal enjeksiyonlar veya kimyasalların yüzeye uygulanması $[5,12,2]$ şeklinde tanımlanmaktadır. Bu tanımlamalar doğrultusunda, taş koruma çalışmalarındaki temel amacın, özgün taşın servis ömrünü uzatmak amacıyla mevcut tașı çıkarmadan birtakım özelliklerini iyileştirerek yerinde korumak olduğu anlaşılmaktadır. $\mathrm{Bu}$ amaçla, taş koruma yöntemleri bir dizi çalışmaları kapsamaktadır. Öncelikle taşın durumu doğrultusunda yüzey temizliği yapılır sonra gerekli görülen durumlarda sağlamlaştırıcı ve/veya su itici kimyasal uygulamalarla koruma ve onarım yapılmaktadır $[13,14,2]$. Taşlardaki yüzey kaybı yapısal özelliklerinin bozulmayacağı şekilde $5 \mathrm{~cm}$ 'den küçük olduğunda özellikle bağlayıcı minerallerin kaybı nedeniyle bozulan taşlarda, taşın mineral bileşenlerinin kohezyonunu iyileştirmek, farklı derecelerde bozulmuş alanlar arasında yapıșma sağlayıp taşın mekanik direncini arttırmak ve yüzey kaybını azaltmak için sağlamlaştırıcı kimyasal uygulamalar $[11,15,16,2]$; taşa su girişi var ise ve bozulma süreçlerini hızlandırıyorsa taştaki yüzey gerilimini azaltarak taşın kirlenmesini geciktirmek ve taşa su ve sulu çözeltilerin nüfuz etmesini önleyerek taşın bozulma oranını düşürmek için su itici kimyasal uygulamalar kullanılmaktadır [2, 11, 15, 17, 20]. 
$\mathrm{Bu}$ çalışma ile, restorasyon ve koruma çalışmaları sırasında kagir yapı malzemelerini sağlamlaştırma uygulamalarında kullanılan sağlamlaştırıcı ve su itici kimyasal uygulamaların, geri dönüşümsüz ve ciddi uygulamalar olduğunu belirterek bu uygulamalara karar verilirken önem verilmesi gereken parametrelere dikkat çekmek; Türkiye'de taş koruma çalışmaları sırasında uygulanacak doğru sağlamlaştırıcı ve su itici kimyasallar için altlık oluşturmak; çok önemli olan bu kimyasal uygulamaların belirli kalitede olmasını sağlamak için Türkiye'de de standartlaşması gerektiğini vurgulayarak bilinçli kullanım konusunda katkı koymak amaçlarıyla uluslararası standartlar ve şartnameler doğrultusunda, taş koruma çalışmalarında kullanılabilecek bir yöntem önerisi geliştirilmiştir.

\section{Materyal ve Metot}

Çalışma kapsamında, yöntem olarak öncelikle kagir yapı malzemelerini koruma çalışmaları için yayınlanan uluslararası standartlar, yönetmelikler ve şartnameler araştırılmıştır. Yapılan araştırma ile;

- 1985 yılında yayınlanan NORMAL 20/85 sayılı Tavsiye Kararının [15],

- 2001 yılında İtalyan NORMAL komisyonunun yayınladığı "UNI 10921: Beni Culturali-Materiali Lapidei Naturali ed Artificiali-Prodotti Idrorepellenti-Applicazione su Provini e Determinazione in Laboratorio delle Loro Caratteristiche" isimli standardın [18],

- İlk olarak 2001 yılında yayınlanan akabinde 2008 yılında revize edilerek yeniden yayınlanan ASTM E2167-01 (2008) kodlu "Standard Guide for Selection and Use of Stone Consolidants" isimli standardin [16],

- 2018 yilında yayınlanan ASTM C1722- 18 kodlu "Repair and Restoration of Dimension Stone" adlı standardin [12],

- Amerika Birleşik Devletleri Savunma Bakanlığı'na bağlı ABD Ordusu Mühendisler Birliği (USACE), Deniz Tesisleri Mühendislik Komutanlığı (NAVFAC), Hava Kuvvetleri İnşaat Mühendisleri Merkezi (AFCEC) ve Ulusal Havacılık ve Uzay Dairesi (NASA) birleşerek mimari ve inşaat alanındaki standartların birleştirilmesi ve aynı işler için aynı standartların uygulanması amaciyla "Unified Facilities Guide Specifications (UFGS)" adiyla oluşturulan kurulun 2017 yılında, yayınladığı "Section 040300 Conservation Treatment For Period Masonry" isimli şartnamenin [11],

- Avrupa Standardizasyon Komitesi tarafindan 2014 yılında yayınlanan BS EN 16581:2014 kodlu "Conservation of Cultural Heritage. Surface protection for porous inorganic materials.
Laboratory test methods for the evaluation of the performance of water repellent products" isimli standardin [17],

- Avrupa Standardizasyon Komitesi tarafindan 2018 yılında yayınlanan BS EN 17114:2018 kodlu "Conservation of cultural heritage - Surface protection for porous inorganic materials Technical and chemical data sheets of water repellent product" isimli standardin [19], dünyada özellikle restorasyon ve koruma çalışmalarında önde gelen ülkelerde, kagir yapı malzemelerini koruma çalışmalarında yardımcı olması için kullanıldığı uluslararası çeşitli çalışmalar incelendiğinde tespit edilmiştir.

Türkiye'de kagir yapı malzemelerinin korunmasına yönelik yayınlanan standartlar incelendiğinde ise, iki standardın yayınlandığı görülmektedir. Yayınlanan standartlardan biri, 2015 yılında yayınlanan TS EN 16581 kodlu "Kültürel mirasın korunması - Gözenekli inorganik malzemeler için yüzey koruma - Su geçirmez ürünlerin performans değerlendirilmesi için laboratuar deney yöntemleri" isimli standarttır [20]. Bu standart incelendiğinde, Avrupa Standardizasyon Komitesi tarafından 2014 yılında yayınlanan BS EN 16581:2014 kodlu "Conservation of Cultural Heritage. Surface protection for porous inorganic materials. Laboratory test methods for the evaluation of the performance of water repellent products" isimli standardın orijinal İngilizce halinin Türkçeye çevrilmeden olduğu gibi kabul edildiği anlaşılmıştır. Yayınlanan standartlardan diğeri ise, 2020 yılında yayınlanan TS EN 17114 kodlu "Kültürel mirasın korunması - Yüzey koruması gözenekli inorganik malzemeler - Teknik ve kimyasal veriler yaprak su itici ürün” isimli standarttır[21]. Bu standartta da, Avrupa Standardizasyon Komitesi tarafindan 2018 yılında yayınlanan BS EN 17114:2018 kodlu "Conservation of cultural heritage - Surface protection for porous inorganic materials - Technical and chemical data sheets of water repellent product" isimli standardın orijinal İngilizce halinin çeviri yapılmadan olduğu gibi kabul edildiği anlaşılmıştır.

Yukarıda belirtilen standartlarda ve şartnamelerde, yüzey uygulamalarına ilişkin çeşitli tanımlamalar yapılmakta olup bu standartlar ve şartnameler, kagir yapı malzemelerinin özellikle özgün taş malzemelerin korunması kapsamında kullanılan sağlamlaștırıcı ve/veya su itici kimyasal uygulamaların doğru seçimine, kullanımına, laboratuvar ve in-situ değerlendirme metotlarına yönelik çeşitli yöntemler önermektedir. Örnek olarak bu standartlardan, ASTM E2167-01 (2008) kodlu "Standard Guide for Selection and Use of Stone Consolidants" " isimli standardın, taş sağlamlaştırıcıların doğru seçimine ve kullanımına yardımcı olmak amacıyla önerdiği yöntem şematize edilerek Şekil 1'de gösterilmiştir. 


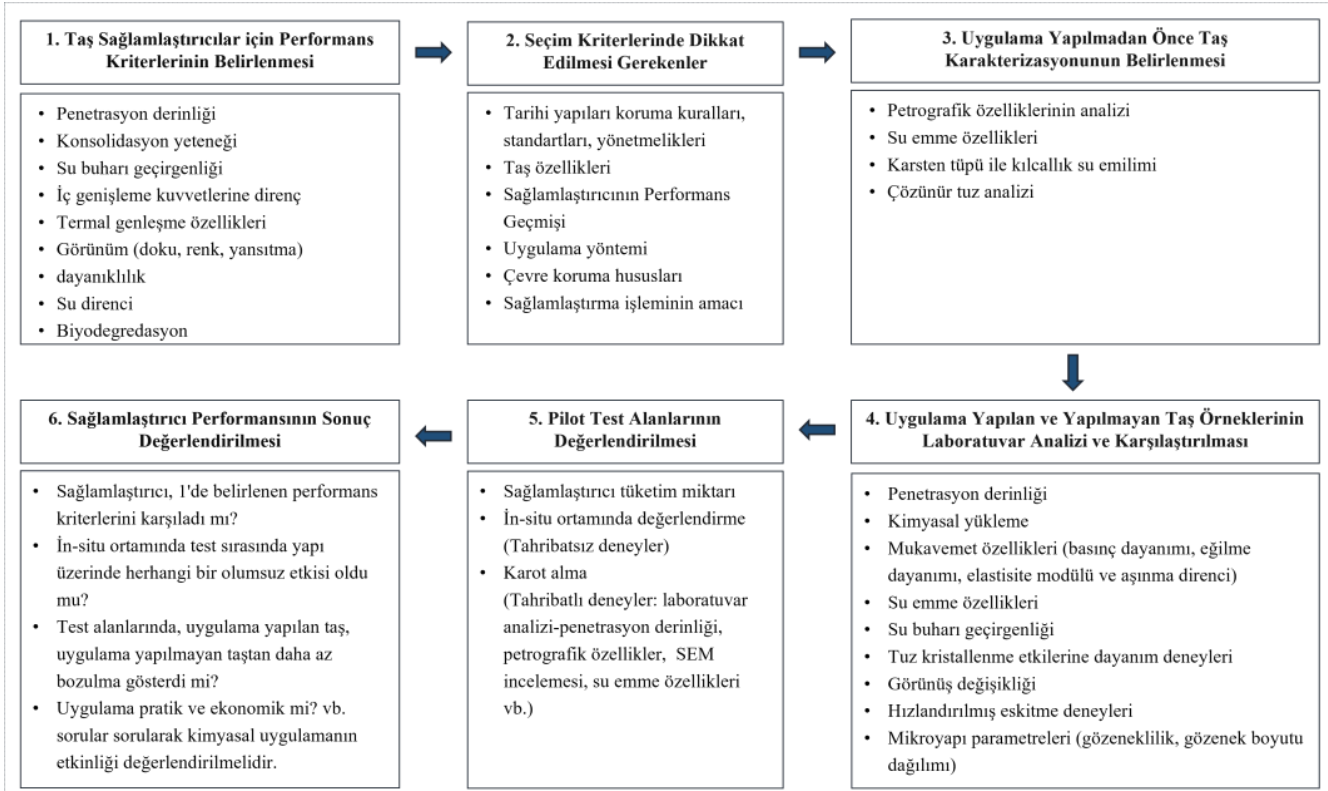

Şekil 1. ASTM E2167-01 (2008) kodlu standardın, taş sağlamlaştırıcıların doğru seçimi ve kullanımına yönelik önerdiği yöntem [2]

Kagir yapı malzemelerini koruma çalışmalarında yapılan sağlamlaştırıcı ve/veya su itici kimyasal uygulamalara ilişkin yayınlandığı tespit edilen tüm standartlardan ve şartnamelerden elde edilen veriler doğrultusunda kagir yapı malzemelerini koruma uygulamalarında kullanılabilecek bir yöntem önerisi geliştirilmiştir.

\section{Bulgular}

Önceki bölümde belirtilen tüm standartlar, şartnameler ve yapılan literatür araştırmaları sonucunda, kagir yapı malzemelerini koruma uygulamalarında kullanılması için geliştirilen yöntem önerisi Şekil 2'de gösterilmiştir. Geliştirilen yöntem önerisi, 6 ana başlıkta ele alınmış olup bu bölümde ayrıntılı olarak açıklanmaktadır.

\subsection{Gözlem, durum analizi ve belgeleme}

$\mathrm{Bu}$ aşamada, yapının tüm çevresiyle birlikte kendi bütünlüğünü ve karmaşıklığını anlamak için yapının genel strüktürü, formu, malzemesi ve çevresiyle ilgili olarak yapıya ilişkin geçmişten günümüze yapılmış tüm araştırmalar toplanır ve detaylandırılır. Bu kapsamda bu bölüm iki alt başlıkta ele alınır. Bunlar; makro gözlem ve mikro gözlemdir.

\subsubsection{Makro gözlem}

Yapının ve alanın tüm mekansal ve geometrik özelliklerini içerir. Bu aşamada, yapının genel yapısı, formu, malzemesi gibi genel özelliklerinin çevresiyle ilişkisinin zaman içindeki değişimi üst ölçekte genel hatlarıyla ele alınır.

\subsubsection{Mikro Gözlem}

Kagir malzemelerin mevcut durumlarını ve kültürel mirasın korunması standardına göre korunmuşluk durumlarını içerir. Öncelikle restorasyon kararını vermeden önce yapıyla ilgili tarihi belgelerin titizlikle toparlanması ve değerlendirilmesi gereklidir. Yapının tarihi, yapım yöntemi, zaman içerisinde yaşadığı değişikliklerle ilgili mümkün olduğunca fazla dokümantasyon, herhangi bir müdahale için gerekli altyapıyı sağlar. $\mathrm{Bu}$ nedenle, yapıyla ilgili tarihi belgelerin bulunup incelenmesi, geçirdiği onarımların kronolojik bir sırada ortaya konması hasar nedenlerinin anlaşılması için atılacak ilk ve en önemli adımdır. Sonrasında yapının korunmuşluk durumunun ve taş türlerinin belirlenmesi gereklidir. Yapıda kullanılmış olan özgün taşın cinsinin ve korunmuşluk durumunun belirlenip belgelenmesi, kagir yapı malzemelerini koruma çalışmaları kapsamında yapılan sağlamlaştırıcı ve su itici uygulamalar için yol gösterici olacaktır [2, 22, 23, 24].

\subsection{Deneysel çalışmalar}

$\mathrm{Bu}$ aşamada, yapıdaki taşların bozulma morfolojilerinin belirlenmesi ve kimyasal uygulama yapılmadan önce sağlam taşların karakterinin belirlenmesi için deneysel çalışmalar yapılmalıdır. Taşların bozulma morfolojilerinin haritalanması için yapının bulunduğu durumun ve detaylarının çeşitli ölçekli çizimlerle (rölöveler) ve yakın çekim fotoğraf, video gibi diğer görsel imkanlarla belgelenmesi gerekmektedir. $\mathrm{Bu}$ çizimler üzerinde taşın hasar tipleri işlenerek hasar lejantları oluşturulur $[2,25]$. Belirlenen hasar tipleri görsel analizlere dayalı olarak belirtilir. Ancak, bozulma derecesinin tespiti için yapılması gereken deneyler vardır.

Sağlamlaştırıcı ve/veya su itici uygulamanın performans değerlendirmesinin yapılabilmesi ve yapı üzerinde kimyasal uygulama yapılıp yapılamayacağına karar verilebilmesi için uygulama yapılmadan önce mutlaka sağlam taşların karakterinin belirlenmesi gerektiğinden yapılması gereken deneyler vardır. Bu doğrultuda, yapı taşının performansı ile ilgili tespit çalışmalarında izlenebilecek deney sistematiği 2 gruba ayrilır [2]. 


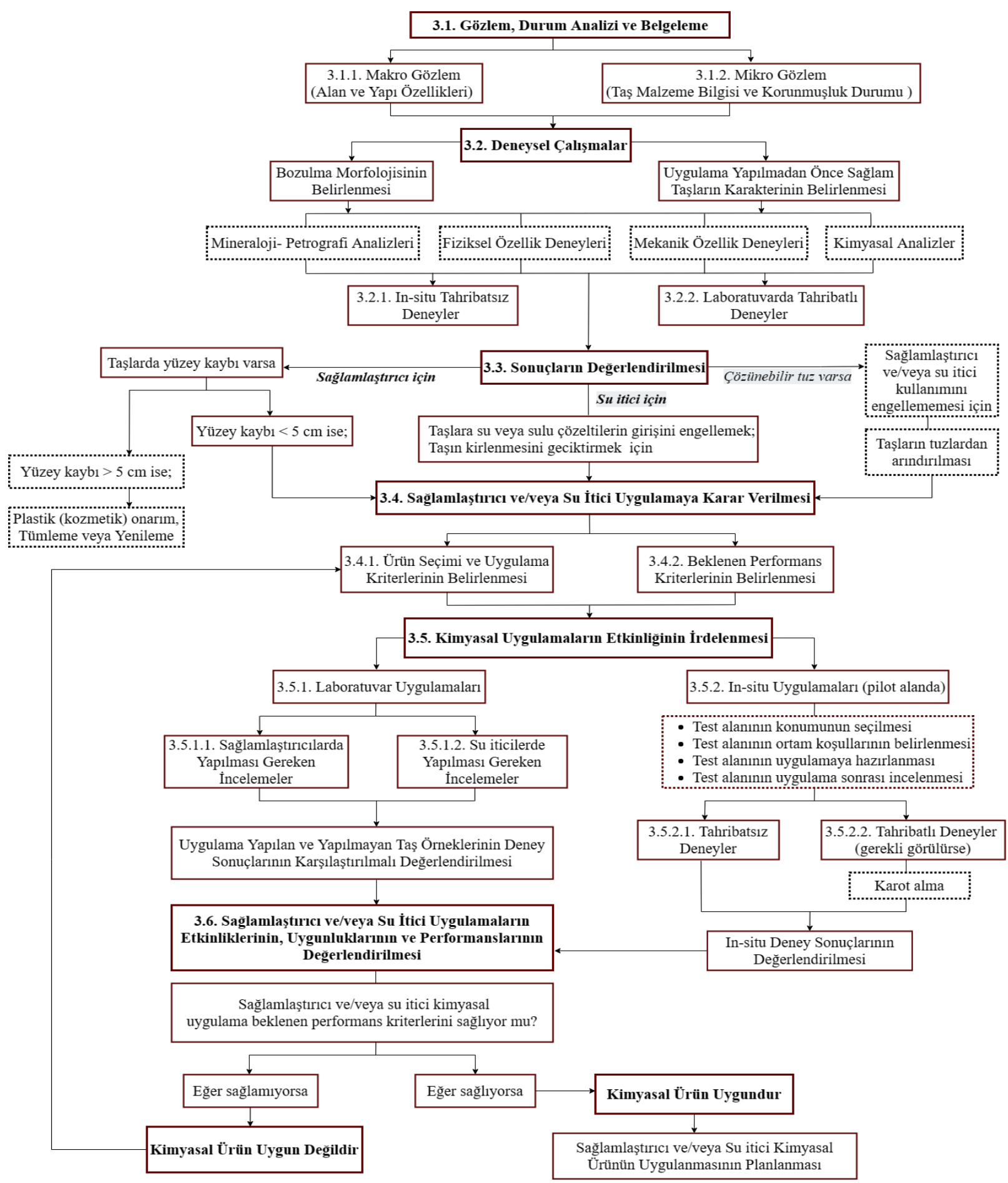

Şekil 2. Kagir yapı malzemelerinin korunma uygulamalarında kullanılabilecek yöntem önerisinin akış șeması [2]

\subsubsection{In-situ tahribatsız deneyler}

Görsel analiz, in-situ deney yöntemlerinin ilk adımıdır. Yapılan görsel analizde, öncelikle taşlardaki bozulmanın başlangıcını gösteren bir veri olan taş üzerindeki renk değişikliği incelenmektedir. Görsel inceleme ile hasarlı olduğu tespit edilen taşlarla ilgili bozulma derecesine, taşın bazı fiziksel ve mekanik özellikleri hakkında bilgi verebilecek tahribatsız ölçümler yaparak karar verilmelidir [2, 23]. Bu deneyler, görsel analiz aşamasında hasar tespitindeki şüpheli durumu ortadan kaldırmak amacıyla yapıldığı gibi daha sonra gerekli görülebilecek laboratuvar deneyleri için de bir ön bilgi sağlamaktadır. Bu yöntemler, taşa zarar vermeden yerinde iken su emme kapasitesi, nem miktarı, çatlaklar, basınç dayanımı, sertlik gibi bazı fiziksel ve mekanik özelliklerinin belirlenmesi için kullanılır [2].

\subsubsection{Laboratuvarda tahribatlı deneyler}

Taşın bozulma morfolojisinin anlaşılması ve sağlam taşın karakter analizinin yapılabilmesi için bu deney yöntemleri kullanılır. Bu deneylerin yapılabilmesi için standartlar doğrultusunda araştırmaya uygun olacak şekilde mümkün olduğunca yapıda göze çarpmayan 
alanlardan çok hassas ve planlı bir şekilde uzmanların ön gördüğü boyutlarda örnek alınması gereklidir [2, $16,17,20,27]$. Taş örnekleri üzerinde petrografik, fiziksel, kimyasal ve mekanik özelliklerin analizi standartlar doğrultusunda yapılabilmektedir.

Mineraloji-petrografi analizleri: Taşın mineral cinsinin ve yapısının anlaşılması için yapılır. Polarize mikroskop altında ince kesitlerin incelenmesi, X-ışını ile (XRD) minerallerin belirlenmesi, SEM-EDX ile mikro strüktür incelemesi vb. analizleri içerir [2, 25].

Fiziksel özellik deneyleri: Bu özelliklerin bilinmesi ile taşın atmosfer şartlarında dayanıklılığı hakkında bilgi sahibi olunur. Taşın fiziksel özelliklerinin önceden bilinmesi farklı iklim bölgelerinde göstereceği davranışı anlayabilmemizi sağlayacaktır. Birim hacim ağırlığı, özgül ağırlık, porozite (gözeneklilik yüzdesi), porozimetri (gözenek boyutu dağılımı), su emme hızı, su emme oranı, kuruma hızı, kılcallık katsayısı, su buharı difüzyon direnç faktörü, doyma derecesi, ısıl genleşme katsayısı vb. analizler fiziksel özellik deneyleridir $[2,25]$.

Mekanik özellik deneyleri: Doğal taşlarla ilgili bazı mekanik özellikler standartlarda verilerek kullanım aşamasında bize kullanımıyla ilgili enformasyonu sağlamaktadır. Doğal taşlar üzerinde yapılabilecek mekanik özellik deneyleri şunlardır; basınç dayanımı, çekme dayanımı, eğilme dayanımı, elastiklik modülü, sertlik deneyleridir [2, 25].

Kimyasal analizler: $\mathrm{Bu}$ analizlerdeki amaç taşta çiçeklenmeye sebep olan suda çözünebilir tuzların varlığını araștırmaktır. Bu tuzlar yağmur sularından, havadaki gazlardan geldiği gibi zeminden de kılcallık yoluyla taşa nüfuz eder ve taşın ıslanma-kuruma döngüleri sonunda kristalleşerek iç gerilmelere sebep olup hasar verirler. Yapilan kimyasal analizler; Klor $(\mathrm{Cl}-)$ analizi, Sülfat $\left(\mathrm{SO}_{4}^{-}\right)^{2}$ ve Karbonat $\left(\mathrm{CO}_{3}^{-}\right)^{2}$ analizi, Nitrat $\left(\mathrm{NO}_{3}{ }^{-}\right)$analizi, Protein analizi, Sabunlaşabilir yağ analizini içerir. Kimyasal analizlerde bulunan kalitatif (element cinsi tayini) ve kantitatif (miktar) tayini ile petrografik ve $\mathrm{x}$ ışınları bilgileri beraberce yorumlanir $[2,25]$.

Sağlamlaştırıcı ve/veya su itici kimyasal uygulama, taşlarda yapılmadan önce, ASTM E2167-01 (2008) kodlu standart doğrultusunda kimyasal analizler sonucunda eğer taşlarda suda çözünebilir tuz varsa sağlamlaştırıcı ve/veya su itici kullanımını engellememesi için öncelikle taşların tuzlardan arındırılması gerekmektedir $[2,16]$.

\subsection{Sonuçların değerlendirilmesi}

Makro ve mikro görsel gözlemler, yapının veya anıtın mevcut durum analizi, belgeleme, in-situ ve laboratuvar ortamında karşılaştırmalı olarak yapılan deneylerin sonuçları değerlendirildikten sonra, özgün taşın bozulma morfolojisi ve sağlam taşların karakteri belirlenmiş olur.
Tüm sonuçlar doğrultusunda yapllacak müdahaleler kapsamında, eğer taşların yüzey kaybı derinliği 5 cm'den fazla ise taşlarda plastik (kozmetik) onarım, tümleme veya yenileme koruma onarım yöntemleri tercih edilebilir. Eğer taşlardaki yüzey kaybı derinliği $5 \mathrm{~cm}$ 'den az ise, özellikle bağlayıcı minerallerin kaybı nedeniyle bozulan taşlarda, taşın mineral bileșenlerinin kohezyonunu iyileștirmek, farklı derecelerde bozulmuş alanlar arasında yapışma sağlayıp taşın mekanik direncini arttırmak için sağlamlaştırıcı kimyasal uygulamalar $[2,11,15,16]$; taşa su girişi var ise ve bozulma süreçlerini hızlandırıyorsa taştaki yüzey gerilimini azaltarak taşın kirlenmesini geciktirmek ve taşa su ve sulu çözeltilerin nüfuz etmesini önlemek için su itici kimyasal uygulamalar $[2,11,15,20]$, taş koruma çalışmaları kapsamında uzmanlar tarafından gerekli görülürse tercih edilebilir.

ASTM C1722- 18 kodlu standartta, taş sağlamlaştırma uygulamaların etkinliğine ilişkin çok az veri olduğu; belirli taşlarda ve çevre koşullarında kullanılmasının, taşlarda renk değiştirme, delaminasyon ve azaltılmış dayanıklılık şeklinde daha fazla zarara neden olabileceği belirtilerek kimyasal uygulama yapılmadan önce kullanıcıların, mutlaka bu alanda uzmanlaşmış kişilerden teknik tavsiye alması gerektiği vurgulanmıştır [12]. Ayrıca, ASTM E2167-01 (2008) kodlu standartta, öncelikle taş bozulmasına neden olan tüm faktörlerin anlaşılması için laboratuvar analizlerinin yaplarak bozulma mekanizmalarının tanımlanması ve taş için koruma planının geliştirilmesi sonrasında sağlamlaştırıcıların kullanımına karar verilmesi gerektiği belirtilmiş olup sağlamlaştırıcı uygulamalar geri döndürülemez bir sürece neden olduğundan, bozulma nedenlerinin kökten giderilemediği ya da değiștirilemediği durumlar sonrası taş sağlamlaştırıcıların kullanılması gerektiği vurgulanmıştır [16]. Standartlarda belirtilen bu koşullar doğrultusunda, sağlamlaștırıcı ve/veya su itici uygulamalara, koruma planı geliştirilirken karar verilmelidir. Ayrıca, sağlamlaştırıcı ve su itici kimyasal uygulamalar, geri döndürülemez bir sürece neden olduğundan, taşlarda bozulma süreçlerinin kökten giderilemediği ya da değiştirilemediği durumlarda, bu alandaki uzmanların koruma süreci içerisinde devam eden teknik destekleri doğrultusunda tercih edilmelidir $[2,12,16]$.

\subsection{Sağlamlaştırıcı ve/veya su itici uygulamaya karar verilmesi}

Taş koruma uygulamaları kapsamında gerekli uzman görüşleri de alınarak yapılan tüm analizler doğrultusunda sağlamlaştırıcı ve/veya su itici kimyasal uygulamalara karar verilmesi aşaması, ürün seçimi yapılarak uygulama kriterlerinin belirlenmesi ve sağlamlaştırıcı ve/veya su itici uygulamalardan beklenen performans kriterlerinin belirlenmesi şeklinde 2 alt başlıkta ele alınmalıdır [2]. 


\begin{tabular}{|c|c|}
\hline 1- ÜRÜNÜN TANITIMI & \multirow{14}{*}{$\begin{array}{l}\text { 1. Kullanım talimatları veya öneri } \\
\text { - Ürūn seyreltilebiliyorsa, önerilen çōzücülerin bir listesi verilmelidir. } \\
\text { - Ürünün kullanımdan önce çalkalanması gerekiyorsa belirtilmelidir. } \\
\text { - Ürünün gözenek boyutu dağılımı veya ortalama gözenekliliği belirlenmiş } \\
\text { gözenekli bir inorganik malzemeye uygun olduğu durumlarda bu } \\
\text { belirtilmelidir. } \\
\text { 2. Uygulama yöntemi ve } \mathrm{m}^{2} \text { başına önerilen miktarlar } \\
\text { 3. Uygulama koşulları } \\
\left(\mathrm{T}\left({ }^{\circ} \mathrm{C}\right) \text { sıcaklık, RH (\%) bağı nem, malzemenin su içeriği vb.) Ayrıca, ürünün }\right. \\
\text { tatmin edici bir performans sağladığı (nüfuz etme derinliği, ürün miktarı, vb.) } \\
\text { koşullar belirtilmelidir. } \\
\text { 4. Ürünün depolanması } \\
\text { 5. Ürünün kullanımdan önce depolanması için sıcaklık aralığı } \\
\text { 6. Ürünün raf ömrü }\end{array}$} \\
\hline 1. Ürünün ticari adı & \\
\hline 2. Üretici & \\
\hline 3. Dağıtım şirketi & \\
\hline 4. Birincil Fonksiyon; Hidrofobik & \\
\hline 5. Fiziksel durumu belirtilmelidir. & \\
\hline \multirow{8}{*}{$\begin{array}{l}\text { 2- ÜRÜNÜN FIZIKSEL, VE KIMYASAL ÖZELLIKLERI } \\
\text { 1. Genel durumu } \\
\text { 2. Fiziksel ve kimyasal özellikler } \\
\text { 3. Aktif bileşenlerin bileşimi } \\
\text { 4. Çözücü } \\
\text { 5. Katkılar } \\
\text { 6. Saflık derecesi ve saflığını bozan maddeler }\end{array}$} & \\
\hline & \\
\hline & \\
\hline & \\
\hline & \\
\hline & \\
\hline & \\
\hline & \\
\hline 3-KURU ÜRÜNÜN ÖZELLLIKLERI & \multirow{7}{*}{$\begin{array}{l}\text { 5-ÜRÜNÜN PERFORMANSI } \\
\text { - Ürünün performansı raporlanmalıdır. } \\
\text { - Performans testleri, üç numune üzerinde EN 16581'de açıklanan test } \\
\text { yöntemlerine göre gerçekleştirilmelidir. } \\
\text { - EN 17036'ya göre ürün performansını değerlendirmek için yapay foto-oksidatif } \\
\text { yaşlanma testleri de yapılmalıdır. } \\
\text { - Ayrıca testi yapan laboratuvarın adı, testlerin yapıldığı tarih gibi bilgiler de } \\
\text { belirtilmelidir. }\end{array}$} \\
\hline Bu, kürleme için gereken süreyi, sıcaklığı ve bağıl nemi belirten & \\
\hline $\begin{array}{l}\text { kuru ürünūn aşağıdaki özelliklerini içermelidir: } \\
\text { 1. Kuru ürünün kütlesi }\end{array}$ & \\
\hline 2. cam geçiş sıcaklığı (polimerik bileşik ise) & \\
\hline 3. ısıl genleşme katsayısı & \\
\hline 4. ortalama molekül ağırlığı & \\
\hline $\begin{array}{l}\text { 5. kuru ürünün kütle yũzdesi yani kuru ürünün çözünūr } \\
\text { fraksiyonu (jel içeriği) }\end{array}$ & \\
\hline
\end{tabular}

Șekil 3. BS EN 17114:2018 kodlu standarda göre, sağlamlaștırıcı ve su itici ürünlerin teknik dokümanlarında belirtilmesi gerekenler $[2,19,21]$

\subsection{1. Ürün seçimi ve uygulama kriterlerinin belirlenmesi}

Sağlamlaştırıcı ve/veya su itici kimyasal uygulamalara karar verilirken ürün seçimi sırasında üretici firmalar tarafından yayınlanan teknik dokümanların ne kadar önemli olduğu yapılan standart araştırmaları sonucunda görülmüştür. Bu teknik dokümanlarda yer alması gereken her bilginin içeriği, BS EN 17114:2018 kodlu standart ile tanımlanmış olup Şekil 3'de şemazite edilerek ayrıntılı şekilde açıklanmıştır. Standartta, kültürel miras alanlarındaki gözenekli inorganik malzemeler üzerinde koruma çalışmalarında kullanılan su itici ürünlerin teknik dokümanlarında; ürünün tanıtımı, ürünün fiziksel ve kimyasal özellikleri, kuru ürünün özellikleri, ürünün kullanımı ve ürünün performansı şeklinde 5 ana başlıkta bulunması gereken bilgiler belirtilmiştir [2, $19,21]$. Ürün seçimiyle birlikte, yapıdaki uygulama yapılacak her malzeme için uygulama yönteminin belirlenmesi gerekmekte olup belirlenen uygulama yönteminin yapıdaki taş çeşidinde uygulanabilirliği, uygulama yapacak çalışanların teknik becerisi, uygulama yapılacak alanın büyüklüğü, uygulamanın hangi koşullarda, ne zaman yapılacağı, uygulama yapılmadan, yapılırken ve yapıldıktan sonra nelere dikkat edilmesi gerektiği gibi birçok parametre de dikkate alınmalıdır [2, 16].

\subsubsection{Beklenen performans kriterlerinin belirlenmesi}

Sağlamlaştırıcı ve/veya su itici kimyasal uygulamalardan beklenen performans kriterleri, bu aşamadaki diğer bir alt bașlık olup uygulama yapılacak taşın maruz kaldığı çevresel faktörler altında tanımlanması gerekmektedir. Sağlamlaştırıcı ve su iticilerden beklenen performans kriterleri, standartlarda ayrıntılı olarak belirtilmiştir. Standartlara göre sağlamlaştırıcı kimyasal uygulamalardan beklenen performans kriterleri, Tablo 1'de özetlenmiştir $[2,15,16,17,18] . \mathrm{Bu}$ performans kriterlerinin yanında, sağlamlaştırıcı uygulamaların, dayanıklı olması, alanda kullanılabilir olması, ekolojik uyumluluk sağlaması, daha sonra yapılabilecek tüm uygulamalarla etkileşiminde engel oluşturmaması ve biyolojik bozulma vb. farklı tür bozulmalara yol açmaması gibi etkenleri de sağlaması gerekmektedir [28].

Standartlara göre su itici uygulamalarda gereken gereksinimler şu şekilde belirtilmiştir $[2,15,17,18$, 20]:

- Farklı bozulmaların oluşumuna yol açmamalıdır.

- Kirleticilere ve oksijene karşı iyi bir kimyasal stabiliteye sahip olmalıdırlar.

- UV radyasyonuna karşı iyi stabiliteye sahip olmalıdırlar.

- Sıvı suyun emilimini azaltmalıdırlar.

- $\mathrm{Su}$ buharı geçirgenliğini azaltmamalı ve minimum değişikliğe neden olmalıdırlar.

- Yüzeyin optik-kromatik özelliklerini değiştirmemelidir.

- Taşın fiziksel ve kimyasal kararlılığını korumalıdırlar.

- Yaşlanmadan sonra bile organik çözücülerde iyi çözünürlüğe sahip olmalıdırlar.

Ayrıca, su itici uygulamalara ilişkin gerekli diğer gereksinimler, kolay uygulanabilmesi, zararlı 
Tablo 1. Standartlara göre sağlamlaştırıcı kimyasal uygulamalardan beklenen performans kriterleri ve özellikleri $[2,15,16$, $17,18]$

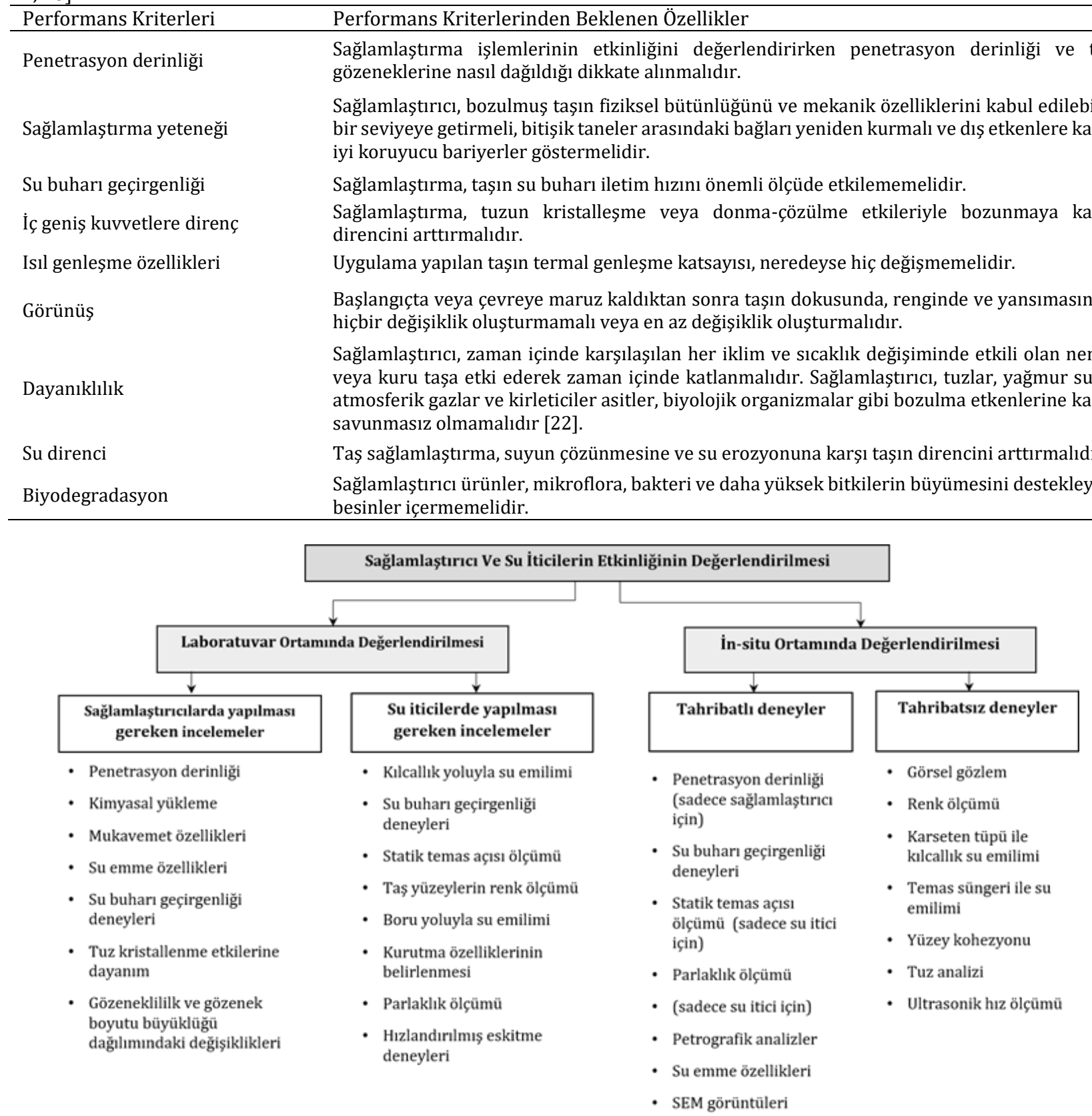

Şekil 4. Sağlamlaştırıcı ve/veya su itici kimyasal uygulamaların etkinliğini değerlendirme yöntemleri [2]

kimyasal gaz salınımı yapmaması için yeterli VOC (uçucu organik madde) seviyesine sahip olması, biyolojik büyümeyi teșvik etmemesi, hidrofobik etkileri kaybolduğunda çlkarılabilir ve/veya yeniden uygulanmasına izin verebilir olmasıdır [2, 29]. Açılklanan bu performans kriterlerini önem sırasına göre tanımlamak sağlamlaştırıcı ve/veya su itici malzeme seçiminde dikkat edilmesi gereken öncelikleri ve bu kimyasal uygulamalarda beklentinin nasıl olması gerektiğini belirlemede yol gösterici olacaktır.

\subsection{Kimyasal uygulamaların etkinliğinin irdelenmesi}

Bu aşamada, sağlamlaştırıcı ve/veya su itici kimyasal uygulamaların etkinliğinin laboratuvarda ve yapıda belirlenen pilot alanlarda in-situ uygulama yapılarak test edilmesi gerekmektedir. Sağlamlaştırıcı ve/veya su itici kimyasal uygulamaların etkinliğini değerlendirme yöntemleri Şekil 4'te gösterilmiştir.

\subsubsection{Laboratuvar uygulamaları}

Kimyasal ürünlerin taş koruma çalışmaları için performans kriterlerini karşılama yeteneğini değerlendirmede yardımcı olur, böylece mevcut ürün sayısı en umut verici alternatiflerden bir veya ikisine düşürülebilir. Laboratuvar programları, önerilen kimyasal uygulamaların kisa vadeli bir değerlendirmesini sağlamanın yanı sıra, sağlamlaştırıcı ve/veya su iticilerin maruz kalacağı özel ortama ve iklime benzer ortamlar oluşturabilecek deney koşullarının ayarlanabilmesini sağlamaktadır 
$[2,22]$. Kimyasal bir malzemenin etkinliği zamanla değerlendirilebildiğinden herhangi bir tedavinin hızlı bir şekilde değerlendirilmesini sağlamak için laboratuvar deneylerine ihtiyaç vardır. Doğal taşın dayanıklılı̆̆ı ve fiziksel- kimyasal özelliklerinin yanı sıra restorasyon ve koruma çalışmaları öncesi ve sonrası hava koşullarına maruz kalmanın etkilerini ölçmek için çeşitli laboratuvar deney yöntemleri geliştirilmiştir[2,33].Bu deneyler; sağlamlaştırıcılarda yapılması gerekenler ve su iticilerde yapılması gerekenler olarak 2 alt grupta ele alınmakta olup Ek A'da sağlamlaştırıcı ve/veya su itici kimyasal uygulamaların değerlendirilmesinde kullanılan laboratuvar deney yöntemleri açıklanmıştır.

\section{Sağlamlaştırıcılarda yapılması gereken laboratuvar deney yöntemleri}

Standartlar ve şartnameler doğrultusunda sağlamlaştırıcı kimyasal uygulamalarda yapılması gereken laboratuvar deney yöntemleri belirlenmiş olup bunlar; penetrasyon derinliği, kimyasal yükleme, mukavemet özellikleri, su emme özellikleri, su buharı geçirgenliği deneyleri, tuz kristallenme etkilerine dayanım deneyleri, görünüş değişimi, hızlandırılmış eskitme deneyleri, gözenekliliği (porozite) ve gözenek boyutu büyüklüğü dağılımındaki değişiklikler şeklinde sıralanmaktadır $[2,16]$. Deney yöntemlerinin açıklamaları Ek A'da gösterilmiştir.

Bu deney yöntemlerine ek olarak uygulama yapılmış ve yapılmamış taş örneklerinde, kilo değişimi, renk değişimi, tamamen daldırma ile su emme, kılcal su emme, düşük basınçlı su emme (su borusu yöntemi), emilen suyun buharlaşma oranı, gözenek boyutu dağılımı, su buharı geçirgenliğ $\mathrm{i}$, penetrasyon derinliği ve mekanik direnç gibi benzer testlerin yapılarak ölçümlerin yapılması önerilmiştir. Ayrıca, sağlamlaştırıcı ürün stabilitesini test etmek için kimyasal saldırıya ve biyolojik oluşumlara karşı dirençli ürün seçilmesi gerektiği belirtilmiștir [2, 15].

\section{Su iticilerde yapılması gereken laboratuvar deney yöntemleri}

BS EN 16581:2014 kodlu standart ile, su iticilerde yapılması gereken laboratuvar deney yöntemleri belirlenmiş olup Şekil 5'de önerilen deney yöntemlerinin akış diyagramına yer verilmiştir. Bu testler; kllcallı yoluyla su emiliminin belirlenmesi, boru yöntemiyle su emiliminin belirlenmesi, su buharı geçirgenliğinin belirlenmesi, kurutma özelliklerinin belirlenmesi, taș yüzeyinde renk, parlaklık ölçümü ve statik temas açısı ölçümüdür $[17,20]$. Bu deney yöntemlerinin açıklamaları Ek A' da gösterilmiştir. Laboratuvar deneyleri uygulama yapılmış ve yapılmamış taş örnekleri üzerinde yapılmalıdır. Seçilen testlerdeki sonuçlar karşılaştırılarak, uygulanan her bir ürünün etkinliğini, uygulama yapılan taş örneklerinden elde edilen taş özelliklerinin iyileşmesine veya kötüleşmesine bakılarak değerlendirmek mümkündür

$[2,17,20]$. Değerlendirme işlemleri, tedaviden kısa bir süre sonra kürlenme yani polimerizasyon süresi beklendikten sonra veya uzun vadeli performansı izleyerek yapılabilir [2].

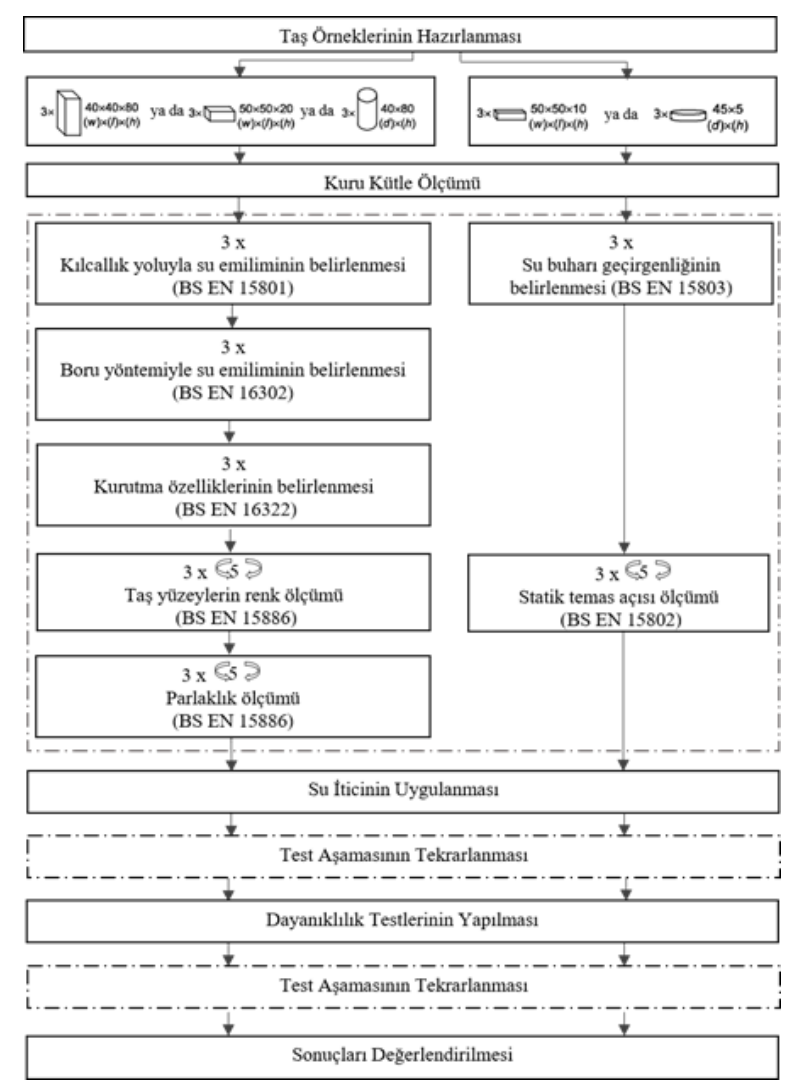

Şekil 5. Su itici kimyasal uygulamalarda önerilen test prosedürünün akış diyagramı $[2,17,20]$.

\subsubsection{In-situ uygulamaları}

Laboratuvar deneylerinin tamamlanmasından sonra, uygulanmasına daha olumlu bakılan sağlamlaştırıcı ve/veya su itici kimyasal uygulamaların test sonuçlarını doğrulamak için in-situ uygulama yapılarak test edilmelidir, böylece en iyi uygulama işlemlerinin belirlenmesi sağlanabilir [2, 33]. In-situ uygulamanın amacı, taş yapının seçilen pilot alanında yapılan uygulama ile sağlamlaştırmaya ihtiyaç duyulan tüm alana uygulama yapılmadan önce sağlamlaştırıcı ve/veya su itici performansı değerlendirilebilmektir [2, 16].

Test alanının konumunun seçilmesi: Öncelikle in-situ test alanı yapılacak yer yani yapıdaki pilot alanların konumu, taşın maruz kalacağı çevresel koşulları temsil edecek şekilde çok dikkat çekmeyecek alandan seçilmeli ve test alanı uygulamaya hazırlanmalıdır. Uygulama yapılan alana benzer bir alan tedavi edilmeden karşılaştırmalı kontrol için bırakılmalıdır. Test alanının seçiminde, taşın mevcut durumu (bozulması, bozulma türü, bozulmanın ilerlemesi), taşın performansını etkileyecek mimari özellikler (çıkıntılar, parapetler, çatılar), mevcut hava koşullarına maruz kalma ve test edilecek özelliğin 
sanatsal ve tarihi önemi dikkate alınması gereken koşullardır $[2,22,16]$.

Test alanının ortam koşullarının belirlenmesi: Hazırlık aşamasında sıcaklık, mevsim, uygulama yöntemi, polimerizasyon süresi, uygulama sırasında ve sonrasında alanın yağmur, güneş gibi birçok faktörden korunması gibi parametrelere de dikkat edilerek bu süreç planlanmalıdır.

Test alanının uygulamaya hazırlanması: Uygulama öncesi hem kontrol alanındaki hem de uygulama yapılacak alandaki taşların durumu fotoğraflarla belgelenmelidir. Test alanında kullanılan prosedürler, tüm yapı üzerinde kullanılacak prosedürlerle aynı olmalıdır. Test alanında kullanılan sağlamlaştırıcı ve su itici kimyasal miktarı, sicaklık ve uygulamanın zamanlaması kaydedilmelidir [2, 19, 21]. Test alanı uygulama sırasında ve kürlenme sürecinde yağmur ve güneşten korunmalıdır. Ayrıca, sağlamlaştırıcı ve/veya su itici uygulama yapılmadan önce, yüzeyde biyolojik bozulma varsa arındirılmalı, sonrasında yüzey mutlaka temizlenmelidir $[2,11,15]$.

Test alanlarının uygulama sonrası değerlendirilmesi: Uygulama yapıldıktan sonra test alanlarının uygulama sonrası değerlendirilmesi gerekmektedir. Uygulamanın polimerizasyon süresi beklendikten sonra veya bir yıl gibi bir süre belirlenip atmosferik şartları maruz kalması sonucunda belirli periyotlarda tahribatsız ve tahribatlı deneyler şeklinde 2 yöntemle in-situ değerlendirilmesi yapılmaktadır [2].

\section{Tahribatsız deneyler}

Sağlamlaştırıcı ve/veya su iticinin etkinliğine ilişkin uygulama öncesi ve sonrasında belirli periyotlarda tahribatsız deneyler yapılarak tedavinin etkinliğine ilişkin gözlem yapılabilir. Bu deneyler; görsel gözlem, renk ölçümü, Karsten tüpü ile su emiliminin ölçümü, temas süngeri ile su emiliminin ölçümü, yüzey kohezyonu, taşın tuz profilinin ölçümü ve ultrasonik hız ölçümüdür $[2,26]$. Sağlamlaştırıcı ve/veya su itici kimyasal uygulamaların değerlendirilmesinde kullanılan in-situ ortamında uygulanan bu tahribatsız deney yöntemleri, Ek B'de açıklanmıştır.

\section{Tahribatlı deneyler}

Eğer tahribatsız deneyler yetersiz bulunursa ve tatmin edici sonuç vermezse uzmanların kararları doğrultusunda yapının uygulama yapılmış alanlarından titizlikle ve gerekli görülen boyutlarda BS EN 16085 kodlu standart vb. standartlar doğrultusunda karot alınarak tahribatlı laboratuvar deneyleri yapmak mümkündür. Penetrasyon derinliği (sadece sağlamlaştırıcı için), statik temas açısı ölçümü ve parlaklık ölçümü (sadece su itici için), su buharı geçirgenliği deneyleri, petrografik analizler, su emme özellikleri, SEM görüntüleri vb. yapılabilecek testler arasındadır $[2,16,17,20]$. Ayrıca, taşın yüzeyinde yapılan sağlamlaştırıcı ve/veya su itici uygulamaların etkinliğini anlamak için eskitme deneylerine ilave olarak islanma-kuruma, bağll nem ve sicaklık çevrimleri, ultraviyole ve kükürtdioksit etkilerine dayanıklılığın test edilmesi gibi deneyler yapılmalıdır. $\mathrm{Bu}$ deneylerin sonuçlarına göre yapılan kimyasal uygulama yönteminin etkinliği, ömrü ve uygunluğu hakkında fikir sahibi olmak mümkündür $[2,22]$.

\subsection{Sağlamlaştırıcı ve/veya su itici uygulamaların etkinliklerinin, uygunluklarının ve performanslarının değerlendirilmesi}

Sağlamlaştırıcı ve/veya su itici uygulamaların etkinliklerinin, uygunluklarının ve performanslarının belirlenmesi için taşlara yapılan tüm laboratuvar ve in-situ deney yöntemlerinin sistemli bir şekilde yapılması gerekmektedir. Başarılı bir sağlamlaştırıcı ve/veya su itici uygulamadan beklenilenler; özgün taşın mineralojik ve kimyasal yapısını değiştirmemesi, fiziksel özelliklerini iyileștirmesi; bununla birlikte sağlamlaştırıcıların taşın mekanik özelliklerini de iyileştirmesi; su iticilerin ise sıvı su ve sulu çözeltilerin emilimini azaltmasıdır.Taşlarda, sağlamlaştırıcılardan mekanik dayanım göstermesi beklenirken su iticilerden fiziksel dayanım göstermesi beklenir. Bununla birlikte, tașın fiziksel özelliklerinden su emme değerini azaltırken buhar geçirgenlik özelliğini azaltmaması beklenir. Tașın nefes alması engellenmemelidir. Ayrıca, tașta renk, doku, parlaklık değişikliği yapmamalı, biyolojik oluşumları teşvik etmemeli, tuz oluşumuna neden olmamalı ve UV ışınlarına karşı iyi bir stabilite göstermelidir. Tüm bu kriterlerin yanında, ekonomik ve ekolojik olması gibi diğer performans kriterlerinin de sağlanıp sağlanmadığına bakılmalıdır [2].

Eğer sağlamlaştırıcı ve/veya su itici uygulama, beklenen performans kriterlerini sağlıyorsa, yapıda veya anitta uygulanacak kimyasal ürün uygun kabul edilmektedir. Daha sonra yapıda veya anıtta büyük ölçekte sağlamlaştırıcı ve/veya su itici ürünün uygulanması için uzman tüm paydaşların kararları ve planlaması doğrultusunda uygulama yapılmalıdır [2, 16]. Eğer sağlamlaștırıcı ve/veya su itici uygulama, beklenen performans kriterlerini sağlamıyorsa, yapıda veya anıtta uygulanacak kimyasal ürün uygun değildir demektir. 0 zaman kimyasal ürün seçimi ve uygulama kriterlerinin belirlenmesi aşamasına geri dönülerek tüm deney sürecinin yeniden planlanması gerekmektedir $[2,16]$.

\section{Sonuçlar}

Dünyada özellikle restorasyon ve koruma çalışmalarında önde gelen ülkelerde taş sağlamlaştırma uygulamaları, tarihi yapıları koruma kuralları, standartlar ve yönetmelikler çerçevesinde yapıldığından Türkiye'de de daha başarılı sonuçlar elde edilebilmesi ve özgün tarihi yapı taşlarında bu uygulamaların daha fazla zarara neden olmaması için 
taş sağlamlaştırma uygulamalarının mutlaka standartlaşması gerektiği görülmektedir.

Taş koruma çalışmalarının planlanması, disiplinler arası bir hiyerarşiye dayandığından taș sağlamlaştırma uygulamaları yapan malzeme firmalarının teknik elemanları ile restorasyon firmalarında çalışıp bu alanda uygulama yapan uzmanların işbirliği içinde bu sürecin planlaması gerekmektedir. Türkiye'de taş sağlamlaştırma uygulamaları araştırılırken bu alanda faaliyet gösteren sayılı malzeme firmasının ve bu konuda yapılmıș sayılı araștırmanın olduğu görülmüș olup bu uygulamalara karar verme sürecinde tereddütlerin olduğu ve bu süreç değerlendirilirken bir altlığa ihtiyaç duyulduğu anlaşılmıştır. Bu kapsamda, yapılan tüm literatür çalışmalarından elde edilen veriler sonucunda, taş koruma uygulamalarında kullanılabilecek bir yöntem önerisi geliștirilmiştir. Geliştirilen yöntem önerisi ile önerilen her aşama, tarihi yapılarda kagir malzemelerin korunması kapsamında sağlamlaştırıcı ve/veya su itici kimyasal uygulamaların doğru seçimine, kullanımına, laboratuvar ve in-situ değerlendirme metotlarına yönelik dünyada yayınlanan uluslararası standartlara ve şartnamelere dayandırılmıştır.

Geliştirilen yöntem önerisi doğrultusunda sonuç olarak şunlara dikkat edilmelidir;

- Sağlamlaştırıcı ve/veya su itici kimyasal uygulamalar, tarihi taş yapılarda bir kez uygulandıktan sonra geri döndürülemez bir sürece neden olduğundan, doğal taşlarda bozulma nedenlerinin kökten giderilemediği ya da değiștirilemediği durumlar sonrasında kullanılmalıdır.

- Sağlamlaştırıcı ve/veya su itici kimyasal ürünlerin teknik dokümanları, standartlar doğrultusunda daha kapsamlı oluşturulmalı, özellikle etkileri belirli bir süre sonra geçtiğinden taş yapılarda ne kadar süre etkilerinin geçerli olabileceği daha net belirtilmelidir.

- Laboratuvar ortamında deneysel uygulamaların önemli sonuçları olsa bile, ayrıca, sağlamlaştırıcı ve/veya su itici uygulamalara karar verilmeden önce etkinliklerinin gözlemlenmesi için mutlaka tarihi taş yapılarda belirlenen küçük pilot alanlarda uygulama yapılmalıdır.

- $\mathrm{Bu}$ konu uzmanlık gerektiren bir konu olduğundan uluslararası standartlarda da açıkça belirtildiği gibi Türkiye'de de tarihi yapı taşlarında kimyasal uygulamalara karar verme sürecinde mutlaka bu alanda uzmanlaşmış insanlardan yardım alınmalıdır.

- Uygulama aşamasında, kagir malzemelerin bulundukları çevrenin de özellikleri dikkate alınarak uygulama yapılmalıdır. Ve uygulamalar sonrası, kagir malzeme yüzeyleri belirli bir süre yağmur ve sudan korunmalıdır.

- Sağlamlaştırıcı ve/veya su itici kimyasal uygulamalarda ekolojik etki de göz önünde bulundurulmalı ve tehlikeli kirletici madde üretmeyen uygulamalar tercih edilmelidir.

Geliştirilen bu yöntem önerisinin, kagir yapı malzemelerini koruma uygulamaları kapsamında sağlamlaştırma çalışmalarında yardımcı olması ümit edilmektedir.

\section{Etik Beyanı/Declaration of Ethical Code}

Bu çalışmada, "Yükseköğretim Kurumları Bilimsel Araştırma ve Yayın Etiği Yönergesi" kapsamında uyulması gerekli tüm kurallara uyulduğunu, bahsi geçen yönergenin "Bilimsel Araştırma ve Yayın Etiğine Aykırı Eylemler" başlığı altında belirtilen eylemlerden hiçbirinin gerçekleştirilmediğini taahhüt ederiz.

\section{Kaynakça}

[1] Çorapçığlu, K., 1983. Doğal Taş Yapılarda Taş Ayrışmasının Nedenleri ve Maktralı Kalkerler Üzerinde Korumaya Yönelik Bir Araștırma. Mimar Sinan Üniversitesi, Fen Bilimleri Enstitüsü, Doktora Tezi, 24s, 33s, İstanbul.

[2] Karkaş, Z.S., 2020. Tarihi Yapıların Cephelerinde Kullanılan Kagir Yapı Malzemelerinde Konservasyon Çalışmalarının İrdelenmesi ve Sistematik Bir Yöntem Önerisi. İstanbul Teknik Üniversitesi, Fen Bilimleri Enstitüsü, Yüksek lisans tezi, 104-129s, 178-186s, İstanbul.

[3] Onat Hattap, S., 2002. Doğal Taş Malzeme Koruyucuların Performans Ölçümünde Deneysel Metot Araştırması. Mimar Sinan Üniversitesi, Fen Bilimleri Enstitüsü, Doktora Tezi, 3-4s, İstanbul.

[4] Ekim, Z.E., 2019. İmrahor Cami ve Restorasyon Öncesi Tespit Çalışması, Giresun Üniversitesi, Karadeniz Sosyal Bilimler Dergisi, 11 (20), 195s, 193- 214.

[5] Croci, G., 1998. The Conservation and Structural Restoration of Architectural Heritage. Computational Mechanics Publications, WIT Press, USA, 41-43s, 92-94s.

[6] Tabasso, M., \& Simon, S., 2006. Testing methods and criteria for the selection/evaluation of products for the conservation of porous building materials. Studies in Conservation, 51, 67-82.

[7] Bromblet, P., Mertz, J., Vergès-Belmin, V., 2002. Monumental: Revue scientifique et technique de la Sous-direction des monuments historiques. Consolidation et hydrofugation de la pierre, 201243. 
[8] Siegesmund, S., Snethlage, R., 2011. 5th, 2014 edition. Stone in Architecture: Properties, Durability. Springer, Chapter 7, 415s.

[9] Doehne, E., Price, C., 2010. Second Edition. Stone Conservation: An Overview of Current Research, Getty Conservation Institute, Los Angeles, USA, 51s.

[10] Charola, A., 1995. Laboratory Tests and Evaluation of Proposed Masonry Treatments, APT Bulletin, Volume 26, No. 4, Preservation of Historic Masonry, 35-39.

[11] Unified Facilities Guide Specifications (UFGS), 2017. Division 04 - Masonry, Section 0403 00, Conservation Treatment For Period Masonry, USACE/ NAVFAC/ AFCEC/ NASA- UFGS, ABD, $10 \mathrm{~s}, 42-43 \mathrm{~s}$.

[12] ASTM C1722-18, 2018. Repair and Restoration of Dimension Stone, American Standards Institute.

[13] Güleç, A., 1997. Tarihi Yapılarda Koruma: Kimyasal Sağlamlaștırıclar ve Koruyucular, Yapı Dergisi Özel Ek 1, 17-22.

[14] Acun Özgünler, S., 2007. Tarihi Yapılarda Kullanılan Volkanik Tüflerin Konservasyonu Üzerine Bir Araştırma : Od Taşı Örneği. İTÜ Fen Bilimleri Enstitüsü Doktora tezi, 17s, İstanbul.

[15] NORMAL 20/85, 1985. Interventi conservativi: Progettazione, esecuzione e valutazione preventiva, Istituto Centrale del Restauro, Rome.

[16] ASTM E2167-01, 2008. Standard Guide for Selection and Use of Stone Consolidants, USA: American Standards Institute.

[17] BS EN 16581, 2014. Conservation of Cultural Heritage-Surface protection for porous inorganic materials-Laboratory test methods for the evaluation of the performance of water repellent products, British Standards Institution.

[18] UNI 10921, 2001.Beni Culturali-Materiali Lapidei Naturali ed Artificiali-Prodotti IdrorepellentiApplicazione su Provini e Determinazione in Laboratorio delle Loro Caratteristiche.

[19] BS EN 17114, 2018. Conservation of cultural heritage - Surface protection for porous inorganic materials - Technical and chemical data sheets of water repellent product, British Standards Institution.

[20] TS EN 16581, 2015. Kültürel mirasın korunması Gözenekli inorganik malzemeler için yüzey koruma - Su geçirmez ürünlerin performans değerlendirilmesi için laboratuar deney yöntemleri, Türk Standartları Enstitüsü.

[21] TS EN 17114, 2018. Kültürel mirasın korunması Yüzey koruması gözenekli inorganik malzemeler - Teknik ve kimyasal veriler yaprak su itici ürün, Türk Standartları Enstitüsü.
[22] Princi, E., 2014. Handbook of Polymers in Stone Conservation, Diagnostic Approaches: Methods of Evaluation, 121-159, Shawbury, Smithers Rapra Technology Ltd., UK.

[23] Menéndez, B, 2016. Non-Destructive Techniques Applied to Monumental Stone Conservation, IntechOpen, Chapter 8, 173-213.

[24] Ekim, Z.E., 2019. İstanbul'daki Misyoner Hastanelerinden Geremia (Jeremia) Hastanesi ve Mimarisi, Tokat Gaziosmanpaşa Üniversitesi Sosyal Bilimler Araştırmaları Dergisi, 14 (2), 697s, 679- 698 .

[25] Acun Özgünler, S., Arıŏlu, N., 2006. A Method Concerning The Preservation And Restoration Works Of The Stones Used In Historical Buildings, Architectural Science Review, Volume 49.2, 1-12.

[26] Svahn, H., 2006. Non-Destructive Field Tests in Stone Conservation, Field and Laboratory Tests, Riksantikvarieämbetet, Swedish National Testing and Research Institute, Sweeden.

[27] BS EN 16085, 2012. Conservation of Cultural property. Methodology for sampling from materials of cultural property. General rules, British Standards Institution.

[28] Tabasso, M., 1993. Materials for Stone Conservation. UNESCO, Congrès International sur la Conservation de la Pierre et Autres Matériaux , 54-58s, Paris.

[29] SWRI, 1994. Clear Water Repellents for Above Grade Masonry and Horizontal Concrete Treatments, Kansas City, Waterproofing and Restoration Institute, ABD.

[30] Kumar, R., \& Ginell, W., 1997. A New Technique for Determining the Depth of Penetration of Consolidants into Limestone Using Iodine Vapor, Journal of the American Institute for Conservation 36, 143-150.

[31] Fassina, V., Arbizzani, R., Botteghi, C., Matteoli, U., Passaglia, E., Aglietto, M., 1994. Stone Monuments, Methodologies for the Analysis of Weathering and Conservation. Proceedings of the 3rd International Symposium on the Conservation of Monuments in the Mediterranean Basin, 911s, Venice, Italy.

[32] Scherer, G., \& Wheeler, G., 2009. Silicate Consolidants for Stone. Key Engineering Materials 391, 1-25.

[33] Becerra, J., Zaderenko, A.P., Ortiz, P., 2019. Basic Protocol for On-Site Testing Consolidant Nanoparticles on Stone Cultural Heritage, Heritage, Volume 2, Issue 4, 2712-2724. 


\section{Ekler}

Ek A. Sağlamlaştırıcı ve/veya su itici kimyasal uygulamaların değerlendirilmesinde kullanılan laboratuvar deney yöntemleri [2]

\begin{tabular}{|c|c|c|c|c|}
\hline Test Yöntemleri & Standartlar ve Yöntemler & Sağlamlaștırıcı & Su itici & Değerlendirme Kriterleri \\
\hline Penetrasyon derinliği & $\begin{array}{l}\text { boyama tekniği, asit aşındırması, } \\
\text { delme direnci, ultrasonik } \\
\text { izleyiciler, polarizasyon } \\
\text { mikroskopisi, elektronik } \\
\text { mikroskopi ve element-dağlım } \\
\text { haritalaması yöntemleri vb. [30,31] }\end{array}$ & $\checkmark$ & & $\begin{array}{l}\text { Sağlamlaştırıcı, taşa ne kadar derin nüfuz } \\
\text { ederse, sağlamlaştırma etkisi o kadar } \\
\text { güvenilir olmaktadır }[2,16] \text {. }\end{array}$ \\
\hline
\end{tabular}

haritalaması yöntemleri vb. [30,31]

\begin{tabular}{|c|c|c|c|c|}
\hline Kimyasal yükleme & $\begin{array}{l}\text { Kimyasal uygulama sonra taş } \\
\text { örneklerinin, sabit kütle elde } \\
\text { edilene kadar sertleşmesine izin } \\
\text { verilir. Kimyasal yükleme hesabı, } \\
\text { toplam numune kütlesinin yüzdesi } \\
\text { olarak ifade edilir. }\end{array}$ & $\checkmark$ & & $\begin{array}{c}\text { Aşırı kimyasal yükleme, taş gözenekliliğini } \\
\text { ve su buharı iletimini azaltacaktır. } \\
\text { Performans hedeflerine ulaşmak için } \\
\text { gereken minimum yükleme deneysel } \\
\text { olarak belirlenerek bu doğrultuda } \\
\text { uygulama yapılmalıdır. Taşın ağırlığındaki } \\
\text { artış, sağlamlaştırma işlemi sayesinde taş } \\
\text { örneğinde yeni bir malzemenin biriktiğinin } \\
\text { göstergesidir [2,16,22]. }\end{array}$ \\
\hline Basınç dayanımı & ASTM C170 / C170M - 17 & $\sqrt{ }$ & & Basınç dayanımını arttırmalıdır $[2,16,22]$. \\
\hline $\begin{array}{l}\text { Eğilme dayanımı ve } \\
\text { elastisite modülü }\end{array}$ & $\begin{array}{c}\text { ASTM C880 / C880M - 18 ASTM } \\
\text { C99 / C99M - 18 ASTM C1352 / } \\
\text { C1352M }\end{array}$ & $\checkmark$ & & $\begin{array}{l}\text { Eğilme dayanımında, dinamik esneklik } \\
\text { modülünde ve statik elastik modülünde } \\
\text { orta derecede artıș beklenmektedir. }\end{array}$ \\
\hline Aşınma direnci & $\begin{array}{c}\text { ASTM C1353 / C1353M ASTM C } \\
\text { 418- } 12 \text { RILEM 25-PEM IV.2 } \\
\end{array}$ & $\checkmark$ & & $\begin{array}{l}\text { Aşınma direncinde orta derecede artış } \\
\text { olmalıdır. }\end{array}$ \\
\hline $\begin{array}{c}\text { Tam daldırma ile su } \\
\text { emilimi }\end{array}$ & $\begin{array}{c}\text { BS EN } 13755 \text { (2002) NORMAL } \\
\text { 7/82 RILEM 25-PEM } 1.1\end{array}$ & $\checkmark$ & $\checkmark$ & Taşta su emilimini azaltmalıdır. \\
\hline $\begin{array}{l}\text { Kılcallık su emilimi } \\
\text { (düşük basınç altında } \\
\text { su alımı) }\end{array}$ & $\begin{array}{c}\text { BS EN 15801:2009 NORMAL 44/93 } \\
\text { UNI 10859 (2000) }\end{array}$ & $\checkmark$ & $\checkmark$ & $\begin{array}{l}\text { Bozulan taşta emilen suda artış olmamalı } \\
\text { ve su penetrasyon katsayısı azalmalıdır. } \\
\text { Özellikle su iticilerin etkinliği için su } \\
\text { emiliminde azalma olmalıdır. }\end{array}$ \\
\hline $\begin{array}{l}\text { Boru yöntemiyle su } \\
\text { emiliminin } \\
\text { belirlenmesi (düşük } \\
\text { basınç altında su alımı) }\end{array}$ & BS EN 16302 & & $\checkmark$ & \\
\hline Su buharı geçirgenliği & $\begin{array}{l}\text { ASTM-E96/E96M-16 NORMAL } \\
\text { 21/85 BS EN 15803: } 2009\end{array}$ & $\checkmark$ & $\checkmark$ & $\begin{array}{l}\text { Sadece çok az su geçirgenlik azalması kabul } \\
\text { edilebilir. }\end{array}$ \\
\hline $\begin{array}{c}\text { Tuz kristallenme } \\
\text { etkilerine dayanım } \\
\text { deneyleri }\end{array}$ & ASTM C88 / C88M - 18 & $\checkmark$ & & $\begin{array}{c}\text { Deneyde ta ağırlık kaybı yüzdesi ölçülür. } \\
\text { Hesaplanan ağırlık kaybındaki artış tuz } \\
\text { direncini gösterir. }\end{array}$ \\
\hline $\begin{array}{l}\text { Hızlandırılmış eskitme } \\
\text { deneyleri }\end{array}$ & $\begin{array}{l}\text { UV ışınına dayanıklılık, Islanma- } \\
\text { kuruma etkilerine dayanıklılık ve } \\
\text { 1Sısal ölçümler, Donma-çözülme } \\
\text { etkilerine dayanıklılık, Tuz } \\
\text { kristallenme etkilerine karşı } \\
\text { dayanıklılı, Asit etkisine karşı } \\
\text { korozyon ölçülmesi } \\
\end{array}$ & $\checkmark$ & $\checkmark$ & $\begin{array}{c}\text { Uygulanan kimyasalların uzun süreli } \\
\text { performans etkilerini değerlendirmek için } \\
\text { hızlandırılmış eskitme deneyleri } \\
\text { yapılmalıdır. }\end{array}$ \\
\hline $\begin{array}{l}\text { Gözeneklilik ve } \\
\text { gözenek boyutu } \\
\text { dağllımındaki } \\
\text { değișiklikler }\end{array}$ & $\begin{array}{l}\text { ASTM E2167-01 (2008) ASTM- } \\
\text { D4404-18 (2018) NORMAL 4/80 } \\
\text { Taşların gözenek yapısındaki } \\
\text { değişiklikleri ölçmek için SEM } \\
\text { görüntülerinden, su emme } \\
\text { özelliklerinden, yüzey alanı } \\
\text { ölçümlerinden ve ultra ses hızı } \\
\text { ölçümü gibi tekniklerden } \\
\text { yararlanılabilir. }\end{array}$ & $\checkmark$ & & $\begin{array}{l}\text { Kimyasal uygulamalar, açık gözeneklilik ve } \\
\text { gözenek boyutu dağlımında çok sınırlı } \\
\text { değişikliklere yol açabilir. Gözenek boyutu } \\
\text { dağılımındaki ufak değişiklikler, taş } \\
\text { dayanıklılığının kötüleşmesine neden } \\
\text { olmamak için genellikle pozitif bir özellik } \\
\text { olarak kabul edilir [31]. En büyük } \\
\text { gözeneklerin minimum \% (yüzdede) } \\
\text { azalması ile açık gözenekliliğin azalmasıdır } \\
{[16] .}\end{array}$ \\
\hline Mikroskobik özellikler & $\begin{array}{c}\text { Optik ve elektron mikroskobu } \\
\text { araştırması (SEM) }\end{array}$ & $\checkmark$ & $\checkmark$ & $\begin{array}{c}\text { Homojen dağılım göstermeli ve taș } \\
\text { bileșenleri ile iyi bağlantı kurmalıdır. }\end{array}$ \\
\hline $\begin{array}{l}\text { Higrik (nem emilimi } \\
\text { ile) ve hidrik (su } \\
\text { emilimi) dilatasyon }\end{array}$ & $\begin{array}{l}\text { RILEM 25-PEM II.7 Genellikle } 20^{\circ} \\
\text { C'de \% 30-90 bağıl nem aralığında } \\
\text { ölçülür. }\end{array}$ & $\checkmark$ & $\checkmark$ & Dilatasyon artışı olmamalıdır. \\
\hline $\begin{array}{l}\text { Statik temas açısı } \\
\text { ölçümü }\end{array}$ & $\begin{array}{c}\text { BS EN 15802: } 2009 \text { NORMAL } \\
33 / 89\end{array}$ & & $\checkmark$ & $\begin{array}{l}\text { Temas açısı }>90^{\circ} \text { olmalıdır. } 90^{\circ \prime} \text { den } \\
\text { büyük değerler iyi yüzey su iticiliğini } \\
\text { gösterir. Değer ne kadar yüksek olursa, o } \\
\text { kadar daha etkili su itici uygulama } \\
\text { yapıldığını gösterir. }\end{array}$ \\
\hline Parlaklık ölçümü & BS EN ISO 2813: 2014 & & $\checkmark$ & $\begin{array}{c}\text { Parlaklık değişmemelidir. (Çok parlak } \\
\text { yüzeyler için } 20^{\circ} \text { geometri; Yarı parlak } \\
\text { yüzeyler için } 60^{\circ} \text { geometri; Mat yüzeyler } \\
\text { için } 85^{\circ} \text { geometri) } \\
\end{array}$ \\
\hline $\begin{array}{l}\text { Kurutma özelliklerinin } \\
\text { belirlenmesi (kurutma } \\
\text { süresi, indeksi) }\end{array}$ & $\begin{array}{c}\text { BS EN 16322: } 2013 \\
\text { RILEM 25-PEM II.5 NORMAL } \\
29 / 88 \\
\end{array}$ & $\checkmark$ & $\checkmark$ & $\begin{array}{c}\text { Kurutma indeksinde, süresinde artma } \\
\text { olmamalıdır. }\end{array}$ \\
\hline
\end{tabular}


Ek B. Sağlamlaştırıcı ve/veya su itici kimyasal uygulamaların değerlendirilmesinde kullanılan in-situ ortamında tahribatsız deney yöntemleri [2]

\begin{tabular}{|c|c|c|c|c|}
\hline Test Yöntemleri & Standartlar ve Yöntemler & Sağlamlaştırıcı & Su itici & Değerlendirme Kriterleri \\
\hline Görsel gözlem & $\begin{array}{l}\text { Fotoğraf, makro fotoğrafçılık } \\
\text { (büyüteç lensleri ile) }\end{array}$ & $\checkmark$ & $\checkmark$ & $\begin{array}{l}\text { Yüzey kaybı, mikro kırıklıklar ve renk } \\
\text { değişimi olmamalıdır. }\end{array}$ \\
\hline Renk ölçümü & $\begin{array}{c}\text { Spektrofotometri ile ölçüm } \\
\text { (NORMAL 43/93) } \\
\text { BS EN 15886 (2010) } \\
\text { Renk atlasları: Munsell, NCS, DIN- } \\
\text { Farbsystem [26] }\end{array}$ & $\checkmark$ & $\sqrt{ }$ & $\begin{array}{l}\text { Kromatik parametrelerde minimum } \\
\text { değişiklik olması ya da hiç değişiklik } \\
\text { olmamalıdır. }\end{array}$ \\
\hline $\begin{array}{l}\text { Karsten tüpü ile } \\
\text { kılcallık su emilimi } \\
\text { (düşük basınç } \\
\text { altında) }\end{array}$ & $\begin{array}{c}\text { Alman Karsten tüpü, RILEM tüpü, } \\
\text { İtalyan pipeti ve Polonya Mirowski } \\
\text { tüpü }\end{array}$ & $\checkmark$ & $\sqrt{ }$ & $\begin{array}{l}\text { Malzemenin su emmesi, malzemenin } \\
\text { gözenek yapısına karşılık gelmekte olup } \\
\text { malzemenin durumu hakkında bilgi } \\
\text { verir. Özellikle su iticilerin etkinliği için } \\
\text { su emiliminde azalma olmalıdır }[2,26] \text {. }\end{array}$ \\
\hline $\begin{array}{l}\text { Temas süngeri ile su } \\
\text { emilimi }\end{array}$ & $\begin{array}{l}\text { Bu yöntem, test sırasında bir } \\
\text { sünger tarafından emilen su } \\
\text { miktarının gravimetrisi ile } \\
\text { değerlendirmeye dayanmaktadır. }\end{array}$ & $\checkmark$ & $\checkmark$ & $\begin{array}{l}\text { Karsten boru yöntemi oldukça kalın taş } \\
\text { tabakalarının su emilimini ölçerken, } \\
\text { temas süngeri yöntemi daha ince üst } \\
\text { tabakalarda aynı özelliği ölçer. Bu } \\
\text { nedenle, taş yüzeyin hemen altındaki su } \\
\text { emiliminin değerlendirilmesi için tavsiye } \\
\text { edilir }[2,22] \text {. }\end{array}$ \\
\hline $\begin{array}{l}\text { Yüzey kohezyonu } \\
\text { (pürüzlülük) }\end{array}$ & $\begin{array}{l}\text { ASTM D4214-07 (2015) Yüzey } \\
\text { pürüzlülük ölçerler (profilometre } \\
\text { /rugosimetre) }\end{array}$ & $\sqrt{ }$ & $\checkmark$ & $\begin{array}{l}\text { Taşta daha fazla yüzey kaybı } \\
\text { olmamalıdır. }\end{array}$ \\
\hline Ultrasonik hız ölçümü & NORMAL 22/86 ASTM-D2845-08 & $\checkmark$ & & Ölçülen ultrasonik iletim hızı artmalıdır. \\
\hline Çözünür tuz analizi & Borelli yöntemi [26] & $\sqrt{ }$ & $\checkmark$ & $\begin{array}{c}50 \mu \mathrm{S} / \mathrm{cm}^{2} \text { civarında iletkenlik } \\
\text { ölçümlerinin genellikle herhangi bir tuz } \\
\text { problemi yaratmadığı sonucuna } \\
\text { varırken, sınır olarak kabul edilen } \\
\text { yaklaşı } 100 \text { ve } 500 \mu \mathrm{S} / \mathrm{cm}^{2} \text { den fazla } \\
\text { ölçümlerde tuzların hasara yol açtığı } \\
\text { kabul edilebilir [26]. }\end{array}$ \\
\hline
\end{tabular}

